\title{
Online and Remote Learning in Higher Education Institutes: A Necessity in light of COVID-19 Pandemic
}

\author{
Dr. Wahab Ali ${ }^{1}$ \\ ${ }^{1}$ Head of Education Department, Fiji \\ Correspondence: Dr. Wahab Ali, Head of Education Department, Fiji. E-mail: wahaba@unifiji.ac.fj
}

Received: April 21, 2020

Accepted: May 12, $2020 \quad$ Online Published: May 18, 2020

doi:10.5539/hes.v10n3p16

URL: https://doi.org/10.5539/hes.v10n3p16

\begin{abstract}
In light of the rising concerns about the spread of COVID-19 and calls to contain the Corona Virus, a growing number of tertiary institutions have shut down in regards to face-to-face classes globally. The Corona virus has revealed emerging vulnerabilities in education systems around the world. It is now clear that society needs flexible and resilient education systems as we face unpredictable futures. A meta-analysis methodology was adopted for this study and pertinent literature was visited to capture the essence of continued learning during these unprecedented times. Findings reveal that universities worldwide are moving more and more towards online learning or E- Learning. Findings also reveal that apart from resources, staff readiness, confidence, student accessibility and motivation play important function in ICT integrated learning. This exploratory paper proposes that staff members should use technology and technological gadgets to enhance learning especially during these exceptional times. Findings also propose online and remote learning as a necessity in times of lock downs and social distancing due to COVID-19 pandemic. It also provides a strong platform for further research.
\end{abstract}

Keywords: technology, digital generation, learning platforms, internet, pedagogy, COVID-19, online teaching

\section{Introduction}

Against the backdrop of the COVID-19 outbreak various policy initiatives are being launched by governments and tertiary institutions across the world to continue teaching activities so as to contain the virus. However, there is ambiguity and disagreement about what to teach, how to teach, the workload of teachers and students, the teaching environment, and the implications for education equity (Zhang, Wang, Yang, \& Wang, 2020). Large-scale, national efforts to utilize technology in support of remote learning, distance education and online learning during the COVID-19 pandemic are emerging and evolving quickly. Literature highlights certain deficiencies such as the weakness of online teaching infrastructure, the inexperience of teachers, the information gap, the complex environment at home, and so forth (Murgatrotd, 2020). However, despite certain limitations, current situation demands action so that the education of the students is not affected in any way. For example, China initiated a Suspending Classes Without Stopping Learning policy to see that learning was not compromised at any time during COVID-19 pandemic lockdown (Zhang et al., 2020). This is one of the many policies China put in place to see that student learning was least affected during national lockdowns and school closures. To tackle the problems, Huang, Liu, Tlili, Yang, \& Wang, (2020) suggest that governments and education providers need to further promote the construction of the educational information, considering equipping teachers and students with standardized home-based teaching and learning equipment, conduct online teacher training and support academic research into online education, especially education to help students with online learning difficulties

According to a UNESCO Report by the end of 2019, Coronavirus (COVID-19) started rapidly spreading worldwide, causing the death of over 3000 people. Subsequently, several countries started initiating relevant strategies to contain this virus, including school closures. Subsequently, as of $12^{\text {th }}$ March forty six countries in five different continents announced school and university closures to contain the spread of COVID-19 (R. H. Huang et al., 2020). As time moved on 500 million children and youth are still threatened with not attending their schools and universities due to national lock downs. International organizations started paying particular attention to the document Education Response in Crises and Emergencies. UNESCO stated in the Education 2030 Incheon Declaration and Framework for Action that countries should:

Provide alternative modes of learning and education for children and adolescents who are not in 
education institutions, and put in place equivalency and bridging programmes, recognized and accredited by the state, to ensure flexible learning in both formal and non-formal settings, including in emergency situations (R. H. Huang et al., 2020, p. 1).

Subsequently, to contain the COVID-19, the Chinese government has banned most-face-to-face activities, including teaching. The Chinese Ministry of Education has launched an initiative entitled Disrupted Classes, Undisrupted Learning to provide flexible online learning to hundreds of millions students from their homes (R. H. Huang et al., 2020). The rapid evolution of Information Communication and Technology (ICT) and the increasing complexity that comes with its exploding potential explains why integration of technology in education continues to receive special attention particularly, in wake of COVID-19 pandemic. The dawning of the new millennium had witnessed the initial entry of the Net Generation into our higher education institutes, which required staff to brace themselves for a new lineage of learners who had distinctive interests and dispositions. This is because their entry in the world was at a time when technological expansion was ubiquitous and widely adopted throughout the world. A previous research undertaken by the author has revealed that students tend to have a strong bonding with ICT (Ali, 2018). These conspicuous perceptions and the massive lockdown in the midst of current COVID-19 pandemic provided the intrinsic motivation for this study.

\subsection{Aim of the Study}

Novel coronavirus and the resulting COVID-19 pandemic have resulted in more schools and HE Institutes faced with the challenge of how to maintain continuity of teaching and learning while facing the threat of extended closures. Subsequently, this study intends to examine how teaching and learning can still continue during such unprecedented times.

Subsequently the study was guided by the following research question:

What are some of the challenges and benefits of integrating online learning in tertiary institutions in response to COVID-19 pandemic?

\subsection{Significance of the Study}

The findings of this study are considered to be of great importance to various stakeholders for several reasons. Foremost, there is a paucity of previous research regarding how tertiary institutions are trying to cope with keeping students engaged during COVID-19 pandemic and the closure of many tertiary institutions globally. This study will help uncover critical areas and contribute to local literature on the subject, which in turn could be used by relevant authorities in improving their education initiatives. Lecturers' may realize the importance of undertaking studies in information technology and online modes as a means of up-skilling their teaching abilities. The finding of this study will rebound to the benefit of HE institutions by providing them important insights into ICT integrated teaching enabling them to strengthen their programs to better prepare lecturers' to deal with the diverse exigencies of the COVID-19 pandemic.

Furthermore the study makes considerable contribution through its findings by revealing the difference between various groups and their attitudes towards the integration of ICT in teaching and learning. Notably, the findings will be of great value to the staff as they are in constant touch with the students and will be able to better understand their behaviour and address online management issues amicably. In a similar vein, it will also present important information to Education authorities about the benefits of ICT integrated learning enabling them to include them as pedagogical reforms in education. In particular, they may have to revisit their curriculum so that ICT knowledge is included in their text at primary and secondary levels. This adaptation would better prepare the students for ICT integrated pedagogy at HE institutions. Subsequently, the recommendations of the study, if implemented, will allow HE institutes to create an interactive and enjoyable learning environment for all students amidst the nationwide lockdown due to COVID-19 pandemic. Learning environments are diverse platforms such as Google Meet, where users engage and interact to learn new skills. While learners can learn in an array of settings, the term refers to the more preferred and accurate alternative to the traditional classroom (Stadler-Altmann, 2015)

\section{Methodology}

An exploratory research design was found to be most appropriate to unveil the salient intricacies associated with online learning especially in wake of COVID-19, the worldwide lockdown and social distancing. Exploratory studies are a valuable means of asking questions to establish baseline information that could be later used as a launch pad for further research. Although qualitative research has long been of interest in the field of psychology, meta-analyses of qualitative literatures also known as meta-syntheses is quite common amongst researchers. A qualitative meta-analysis commonly known as meta-synthesis allows for systematic review of qualitative studies 
in a way that is more interpretive than aggregative. Meta-analysts are encouraged to consider the methodological integrity of their studies in relation to central research processes, including identifying set of primary research studies and transforming primary findings into categories or themes in an organized manner (Levitt, 2018). Likewise, this process uses rigorous qualitative methods to synthesize existing qualitative studies to construct greater meaning through an interpretative process.

\section{Findings and Discussion}

The ensuing sections present the findings in collaboration with pertinent literature on the influence of technology in conceptualizing pedagogy and practice at HE level.

\subsection{World Context}

According to World Health Organization there are 1699595 confirmed COVID-19 cases in the world, with 106 138 confirmed deaths and the virus has affected 213 countries as at $12^{\text {th }}$ April, 2020.

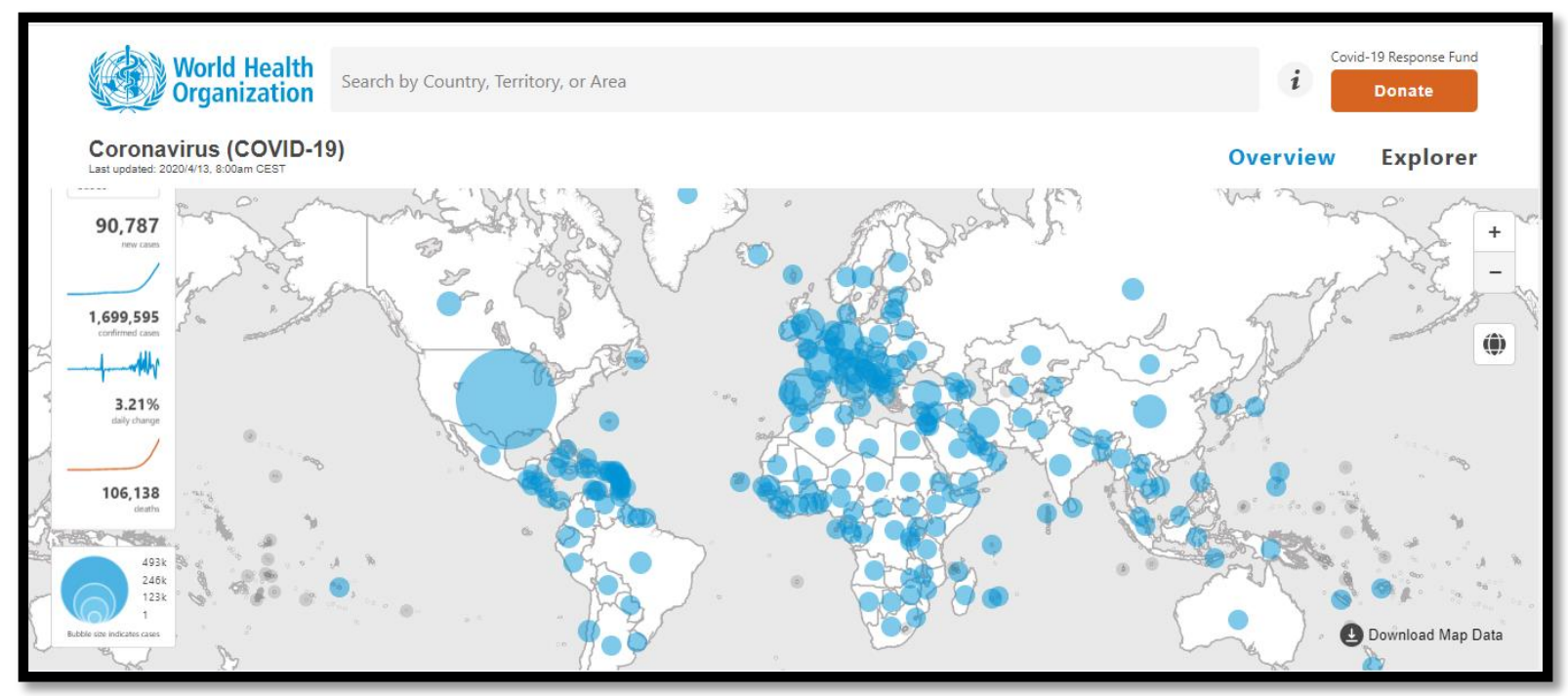

Figure 1. Ref: https://who.sprinklr.com/

In the emerging and ever-changing COVID-19 context (See Figure 1), many countries are being affected by COVID-19. Likewise, many universities are either closed or on the verge of closing physically and are moving towards online and remote learning. For example, New York University Shanghai and Duke Kunshan University offer examples of successful adaptation and rapid deployment of educational technology products, like the video-conferencing platform Zoom and Moodle. Significantly, these universities had existing experience with these technologies that they were able to expand; they weren't starting from scratch with new and untested tech solutions (Czerniewicz, 2020). Likewise, some schools in Australia have struggled with accommodating the rapid switch to online learning. In like manner, institutions have rapidly innovated and implemented online learning, due in part to established familiarity with the necessary tools, teaching approaches and considerations with online learning. This has resulted in less disruption for many students unable to return to in-person classes.

There is no doubt that institutions that lack such preparation and planning measures, need to put in place now in order to avoid the excessive demands and tensions that come from adopting things quickly. There is a clear need for post-secondary online learning expertise in this crisis and it should serve as a reminder that institutions need to cultivate this competency. The mass closure of universities in the EU was done to slow down the spread of COVID-19, the respiratory infection that has now killed more than 106138 people worldwide. Governments' world over are looking for measures that will keep students safe, while finding ways to continue to provide courses online. Literature shows that education administrators are urging staff to cooperate and share know-how and digital infrastructures for teaching online in the quarantined and locked down areas (Czerniewicz, 2020). Countries most affected by the virus are doing their best to continue teaching. For example, Italy was the first EU member state to close its universities and move courses online, before the entire country was placed under quarantine.

Similarly, Denmark, Greece, Ireland, Hungary and Poland have followed suit and suspended face-to-face 
teaching in all universities. Likewise in Italy, the University of Bologna extended deadlines for tuition fees and distributed free SIM cards to students without access to internet. Notably, in Romania, after the government closed all schools, several universities moved their courses online as a precaution. Since social distancing is as important as being locked out universities across Europe are scrambling to set up technical systems needed to move courses, exams, research and other activities online. The University of Warsaw has cancelled all lectures and classes unless conducted on-line. By the same token, Belgium has decided to move lectures online "to the extent possible" and cancelled large-scale events. Staff members have been asked to work from home as much as possible. Literature reveals that universities globally are assuming responsibility, and are doing everything they could do to slow down the further spread of the Corona virus. According to Czerniewicz (2020), this change is inevitable as the current COVID-19 situation demands it for the safety of students and the teaching staff.

\subsection{Politics of Resistance}

Education administrators know that technology is never neutral and any change has certain amount of resistance and contention. Undue protests and dissents during COVID-19, regarding the decision to use "online" and "blended learning" has become political and is politicized a lot. Blended learning has been drawn into existing political agendas and extreme claims have been made such as one mode is better than another (Czerniewicz, 2020). Conspiracies have flourished and those with limited ICT knowledge have paddled unfounded lies about online and blended learning (Zhang et al., 2020). Some people believe face-to face is superior to online and blended mode. This current period is also likely to evoke political responses, in ways that we may not expect. Literature further entails that fake news such as inferiority of online and blended mode as compared with face-to face mode certainly infiltrates the system and further creates chaos and uncertainty. However, some administrations are arguing and discussing as to what needs to be done, while some have already started venturing into online learning. The World Bank believes that little research attention has been paid to documenting and analysing attempts of education systems moving swiftly and at scale to provide online learning when all or many schools and universities are closed (World Bank, 2020b). Even UNESCO is aware that transitioning to online learning at scale is a very difficult and highly complex undertaking for education systems, even in the best of circumstances but states it has become a necessity (UNESCO, 2020).

During the period of protests and disagreements, universities have started going online differently, shaped by their specific institutional contexts. This means not only designing strategies appropriate for specific contexts, but also being aware that technological decisions will be shaped in ways that reflect existing differences, alliances, discourses and perspectives in particular institutions (Murgatrotd, 2020). It may feel like the last thing on one's mind, but it is important to be aware of what message is being sent when explaining the need to replace face-to-face teaching with virtual alternatives. At the time of the protests, the general term used has been blended learning. All university entities need to work cooperatively to effectively launch online and distance learning. Curriculum and other logistics need to be considered and assessment tasks need to be revisited and replaced with assignments to avoid face-to-face final examinations. Acceptance and compliance by all stakeholders will minimise resistance and in turn will facilitate the implementation of online and remote learning especially in times of calamity like COVID-19 pandemic.

\subsection{Infrastructure Support}

The World Bank is mindful of the fact that few education systems, even the most high performing, may not be that well equipped to offer online learning for all students at such a large scale. Technological advances often outpace the ability of decision makers to keep up considering the cost and infrastructure support (World Bank, 2020b). It must be established that to deliver effective online and blended learning there needs to be appropriate ICT support in way of infrastructure and tools as well as hardware and software support system. There is no doubt that the integration of the ICT as an instructional device in academic courses has escalated at a rapid rate. Subsequently universities and colleges have started implementing applications like Moodle and educational Blogs to supplement existing pedagogy and practice (Becker, 2000). Likewise, Ruzgar (2005) agrees with (Becker, 2000) that it is common in universities and colleges to provide online resources to supplement traditional teaching methods. In a study undertaken by Laird and Kuh (2001) confirm that students' responses to the technology related items imply that majority of them use information technology. As such, going online is not seen as a big change for many universities in the world. However, students' readiness and access to technological gadgets needs to be considered at all times.

Meta-synthesis of pertinent literature reveals that in recent years, there has been an increasing interest in the development and use of multimedia-enhanced content through the use of ICT to enhance the quality of teaching and learning (CoSN, 2020; Smith \& Judd, 2020; UNESCO, 2020; World Bank, 2020b). Multimedia contents are 
digital instructional materials that combine text, graphics, audio, and animations. Teachers tend to use these content to liven up classroom lessons by using them to better demonstrate and explain difficult concepts that cannot be easily explained using text alone (Lanzilotti, Ardito, Costabile, \& De-Angeli, 2006; Thomas \& Israel, 2013). Studies have indicated that the appropriate use of multimedia-enhanced content in educational context provides several benefits. According to Lee, Hsiao and Ho (2014) use of ICT tools can help to improve students' understanding of instructional materials. They can also simulate real processes and allow learners to execute virtual experiments that would, otherwise be perilous and expensive to be conducted in a school laboratory (Hennessy, Deaney, \& Ruthven, 2006). In particular, there is a need to accelerate the pace of technology iteration, and optimize the technical application of online education programs considering the alarming impact of COVID-19 pandemic.

\subsection{Staff Readiness}

Meta-synthesis reveals that willingness to embrace change is a major requirement for successful integration of technology as it provides students opportunities to learn and apply the required 21st century skills (Ertmer \& Otternbreit-Leftwich, 2019; Fullan, 2013; Lilllejord, Børte, \& Ruud, 2018). Given the relentless advent of ICT in education arena, its use in enhancing lesson delivery has been widely discussed and adopted in many HE institutions globally. This is because technology acts as a catalyst and supports staff members in lesson preparation and delivery (Sadegül Akbaba, Kalayci, \& Avci, 2011). American Psychological Association, as one of its recommendations has encouraged lecturers' to reckon implementing ICT integrated learning environment for students (Li, Yamaguchi, \& Takada, 2018). In this regard, Vrasidas (2015) is quite sceptical as institutions may have necessary ICT facilities, but there may be other shortfalls such as lack of time for lesson preparation and unsupportive curriculum design. He reiterates that just having the resources does not imply that ICT can be easily implemented but there needs to be the presence of other supportive factors and one such factor is staff readiness (Vrasidas, 2015). That is why Yunus (2007) is assertive that before ICT can be effectively integrated lecturers' should be provided adequate training and support in ICT and pedagogy. There is no doubt why staff readiness and motivation needs to be considered as important factors for the successful assimilation of technology in HE institutions.

In an earlier study undertaken by the author, revealed that some of the staff members in a tertiary institution seem to be integrating ICT in their lessons especially during lectures and tutorials however, majority (92\%) of them still believe that confidence is a factor that can be further enhanced (Ali, 2019). This lack of confidence could be due to the administration of the different tools and learning platforms. On similar note, Huang \& Liaw (2005) are assertive that staff members' attitude and their willingness to implement ICT makes a big difference in the lives of their students. This is because if staff are unwilling and do not implement ICT embedded learning, their students can be just left to rote learning and 'chalk and board' explanations. Similar sentiments are shared by Yuen and Ma (2002) who strongly recommend the need to empower teaching staff and build their confidence so that they are able to implement ICT integrated teaching. Considering COVID-19 pandemic, World Bank stresses that staff working online need to be trained and supported. They further warn that staff who do not have access to sufficient broadband and a connected device at home will obviously not be able to support student learning online (World Bank, 2020b). Subsequently, they urge that staff need to be supported technically, socially and morally so that they can effectively deliver online classes.

\subsection{Student Accessibility}

Students of today are known by many names, like digital natives (Prensky, 2001), millennial (Howe \& Strauss, 2000), net generation (Tapscott, 1998) and digital generation (Wahab Ali, 2018). Their entry in the world was at a time when technological expansion was ubiquitous and widely adopted throughout the world. A previous research undertaken by the author has revealed that students tend to have a strong bonding with ICT (Wahab Ali, 2018). Today's children are exposed to technological gadgets such as mobile phones and tablets from very tender ages the world over (Shava, Chinyamurindi, \& Somdyala, 2016). An empirical study undertaken by Jesse (2015) confirms the aforementioned comment as his findings reveal that majority (99.8\%) of the students have access to have mobile phones and they use it for texting, visiting social media and applications apart from talking. Looking at the rate at which technology is integrated in the education system, it can be assumed that students' display a high degree of acceptance and receptiveness towards it (Willms \& Corbett, 2003).

Likewise, there are certain paradoxes and delusions associated with net generation that needs to be considered as the belief that they know all about ICT is a fatal misconception. Similar sentiments are shared by World Bank (2020a) that by simply pointing students and teachers to large online repositories, without appropriate guidance would not auger well during the COVID-19 pandemic lockdown. For despite they may be technology canny, 
they may lack the theoretical knowledge base required for particular occupation. Evidence for in support can be found in the study of O'Sullivan (2018) who strongly advocates that many young people, the so-called digital natives, have shown limitations in their use of technology. There have been numerous studies worldwide and one such study in 2014 signposted a huge disparity between young people's false impression and their real knowledge of computer skills (Sommer, 2014). Considering COVID-19 pandemic World Bank further reiterate that most students will have great difficulty accessing online learning, especially those staying that have poor Internet access and are subject to numerous other disadvantages (World Bank, 2020b).

\subsection{Making it Happen}

There is no doubt that ICT has become an integral part of everyday life and has transformed the learning environment to the extent that ICT literacy has become a functional requirement for nearly all qualifications. The integration of technology in education has not only changed how students learn but has also changed the teaching pedagogies by promoting collaborative activities (Haddad, 2003). The online learning environments foster additional learning experiences where learners can interact, collaborate, and take ownership of their own learning at their own pace and time. Hence, ICT immersed lessons provide a motivating and encouraging learning environment for our students and also it leads to self-directed learning. When there is a shift from a teacher-controlled environment to a more learner controlled environment, the role of the educator becomes more of a facilitator and minimal scaffolding may be required (Geng, Law, \& Niu, 2019). Obviously, the teaching staff members in form of professors, lecturers and teaching assistants are the key players in the effective implementation of ICT integrated learning (Aydin, 2012; Buabeng-Andoh, 2015; Sipilä, 2011). As such, it is pivotal that they have the right attitude and perceptions about ICT so that they can integrate technology effectively in teaching. Likewise, students' perceptions and aspirations also need to be considered as it directly affects their learning space and style (Buabeng-Andoh \& Totimeh, 2012; Fu, 2013; Jung, 2005; Mirzajani, Mahmud, Fauzi Mohd Ayub, \& Wong, 2016). The unprecedented situation in wake of COVID-19 has brought about challenges to staff, students and administrators to adopt online learning despite certain shortfalls in its organization and implementation.

There is no doubt that massive technological advances in the world demand a paradigm shift in way we approach our educational goals and aspirations. Many universities and educational institutions have adopted ICT tools such as laptop, projectors, tablets, smart phones, ipads and interactive white boards to mention a few. This is apart from many educational softwares and learning applications readily available on the internet. Likewise, the findings reveal that staff members have found that students have a special bonding with ICT. They further believe that todays' students are quite attached to mobile technology and look forward to technology integrated learning. None the less, students' receptiveness of ICT is well acknowledged by all. On similar note, Buabeng-Andoh and Yidana (2014) are in acquiesce with the views of Earle (2002) that students look forward to ICT integrated learning and as it enables them to use internet and catch up with lessons from the comforts of their homes. This impetus in students calls for lecturers and administrators to have adequate ICT infrastructure and student support services to make learning meaningful and enjoyable for all. In essence, it can be concluded that lecturers and teaching staff in general are key stakeholders in the successful implementation of ICT integrated learning and reciprocally they need to be valued and assisted accordingly.

However, the World Bank has highlighted a number of challenges as education providers are rushing to go online so that education of the students are least affected in times of social distancing amidst COVID-19 pandemic. Some of the issues raised by it are as follows:

- Transitioning to online learning at scale is a very difficult and highly complex undertaking for education systems, even in the best of circumstances;

- Moving to online learning at scale raises profound equity concerns;

- Highly motivated learners, especially those with previous experience in online learning, are the most likely to take the most advantage of online learning opportunities;

- When first going online, education systems and parents should expect dips in student achievement in the short term;

- Organizing digital educational content to align with existing curricula can be critical in providing users and teachers with a way to ensure that the learning opportunities provided correspond to broader educational objectives within an education system;

- Making content available on a wide variety of devices and mobile friendly is critical;

- Supporting the use of low bandwidth including offline solutions is key to effective learning;

- Staff teaching online need to be supported; 
- Universities need to negotiate with internet vendors to help provide access to online learning for students for free or at a cheaper rate

- Providing supplemental guidance and support on how to use and access remote and online learning content can be critical; and

- Some academic subjects are easier to move online than others (World Bank, 2020b)

World Bank goes further and states that academic subjects that are largely lecture-based and lend themselves to self-study are easier to move online quickly. Subjects in which learning content has already been digitized, especially where it is explicitly aligned with official school curricula, offer better candidates for online learning in the short term than those that do not. World Bank also cautions all to be aware that much of what happens in classes cannot be easily transferred online. Instructional approaches, content, pacing, interaction models, and assessment may all need to be adapted when transitioning to online learning (World Bank, 2020b). All these processes may be time consuming but a start needs to be made as it is not a matter of choice but a necessity in response to COVID-19 pandemic.

\subsection{Limitations}

Naturally, studies do have certain limitations and in this case it was the single method used to collect data. The results in this study could not be verified by other means such as survey and other independent measures as only meta-analysis was used in the study. Consequently, these results should be viewed as a snapshot of online learning as an option in higher education in light of the drastic impact of COVID-19 pandemic. Thus, the exploratory findings present a solid platform for debate and discussion and a solid launch pad for further in-depth research on the subject matter.

\section{Recommendations and Conclusions}

Taking into consideration the deadly COVID-19 and in its endeavour to avoid its spread governments' worldwide have put in place stringent measures such as national lockdowns and social distancing initiatives. These restrictions have led many universities and HE Institutes to opt for online learning to curtail the spread of Corona Virus. As such it is recommended that:

- The concerns raised by the World Bank identified in this article needs to be taken into consideration when adopting online and remote learning;

- HE Institutions need to have basic ICT Infrastructure to effectively roll out online learning;

- Staff need ICT tools and should have access to applications and learning platforms;

- Staff members also need to have the capacity to use the ICT tools effectively to offer lessons in such a mode; and

- Staff and student readiness needs to be fathomed and supported accordingly.

Moreover, COVID-19 pandemic and social distancing requirement has presented undue challenges on all stakeholders to go online as they have to work in a time constraint and resource restraint situation. It must be established that adopting online learning environment isn't just a technical issue. It is a pedagogical and instructional challenge. As such, ample preparation in regards to teaching materials and curriculum and assessment knowledge is vital in online education. Technology is the means for delivery and requires a close cross-collaboration between instructional, content, and technology teams. Closing universities and taking students and lecturers out of the classroom is a pedagogical transformation that requires rapid mobilization across all university staff and resources (CoSN, 2020).

In essence, ICT has become a potent force in transforming the educational landscape the world over. However, preparing to move education outside of traditional physical classrooms in response to COVID-19 requires thought, coordination and careful decision-making. This document is a starting point for planning and supporting a significant learning transformation. We need to be optimistic as literature entails a high level of student satisfaction and interest in ICT immersed learning environment. There has obviously been a great influence of technology in the online lives of young people. This digitalised revolution can synergise the educational ambitions and interests of the students who have become digital addicts. In essence, COVID-19 has provided us with the opportunity to adopt online learning as education systems need to be abreast with the rapid emergence of new technologies, thus making online, blended and remote learning a necessity at tertiary level not only in Fiji but the world over.

\section{Reference}

Ali, W. (2018). Influence of Evolving Technology in Emerging Online Lives of the Digital Native University 
Students. Asia Pacific Journal of Contemporary Education and Communication Technology, 4(2), 141-155. https://doi.org/10.25275/apjcectv4i2edu15

Ali, W. (2018). Transforming Higher Education Landscape with Hybrid/Blended Approach as an evolving Paradigm. Journal of Advances in Social Science and Humanities, 3(7), 143-169.

Ali, W. (2019). The Efficacy of Evolving Technology in Conceptualizing Pedagogy and Practice in Higher Education. Journal of Higher Education Studies, 9(2), 81-95. https://doi.org/10.5539/hes.v9n2p81

Aydin, S. (2012). A review of research on Facebook as an educational environment. Educational Technology, Research and Development, 60(6), 1093-1106. http://dx.doi.org/10.1007/s11423-012-9260-7

Becker, H. J. (2000). Who's wired and who's not: Children's access to and use of computer technology. The Future of Children, 10(2), 44-75. https://doi.org/10.2307/1602689

Buabeng-Andoh, C. (2015). ICT usage in Ghanaian secondary schools: teachers' perspectives. The International Journal of Information and Learning Technology, 32(5), 300-312. https://doi.org/10.1108/IJILT-09-2015-0022

Buabeng-Andoh, C., \& Totimeh, F. (2012). Teachers' innovative use of computer technologies in classroom: A case of selected Ghanaian schools. International Journal of Education and Development using Information and Communication Technology, 8(3), 22-34.

Buabeng-Andoh, C., \& Yidana, I. (2014). An investigation of secondary school students' attitudes toward pedagogical use of ICT in learning in Ghana. Interactive Technology and Smart Education, 11(4), 302-314. https://doi.org/10.1108/ITSE-10-2013-0024

CoSN. (2020). COVID-19 Response: Preparing to Take School Online. Retrieved from https://www.cosn.org/sites/default/files/COVID-19\%20Member\%20Exclusive_0.pdf

Czerniewicz, L. (2020). What we learnt from "going online" during university shutdowns in South Africa. Retrieved from https://philonedtech.com/what-we-learnt-from-going-online-during-university-shutdowns-in-south-africa/

Earle, R. S. (2002). The Integration of Instructional Technology into Public Education: Promises and Challenges. Educational Technology \& Society, 42(1), 5-13.

Ertmer, P. A., \& Otternbreit-Leftwich, A. T. (2019). Teacher technology change: How knowledge, confidence, beliefs, and culture intersect. Journal of Research on Technology in Education, 42, 255-284. https://doi.org/10.1080/15391523.2010.10782551

$\mathrm{Fu}$, J. S. (2013). ICT in Education: A Critical Literature Review and Its Implications. International Journal of Education and Development using Information and Communication Technology, 9(1), 112-125.

Fullan, M. (2013). Stratosphere: Integrating Technology, Pedagogy and Change Knowledge. Toronto: Perason.

Geng, S., Law, K., \& Niu, B. (2019). Investigating self-directed learning and technology readiness in blending learning environment. International Journal of Educational Technology in Higher Education, 16. https://doi.org/10.1186/s41239-019-0147-0

Haddad, W. D. (2003). Is instructional technology a must for learning? Retrieved from http://www.techknowlogia.org/TKL_active_pages2/CurrentArticles/main.asp?IssueNumber=19\&FileType= HTML\&ArticleID $=455$

Hennessy, S., Deaney, R., \& Ruthven, K. (2006). Situated expertise in integrating use of multimedia simulation into secondary science teaching. International Journal of Science Education, 28(7), 701-732. https://doi.org/10.1080/09500690500404656

Howe, N., \& Strauss, W. (2000). Millenials Rising: The Next Great Generation. New York: Vintage Books.

Huang, H. M., \& Liaw, S. S. (2005). Exploring user's attitudes and intentions toward the web as a survey tool. Computers in Human Behavior, 21(5), 729-743. https://doi.org/10.1016/j.chb.2004.02.020

Huang, R. (2001). Tomorrow's hope: The status quo and development of Chinese educational informatization. Computer Journal, 62, 16-17.

Huang, R. H., Liu, D. J., Tlili, A., Yang, J. F., \& Wang, H. (2020). Handbook on Facilitating Flexible Learning During Educational Disruption: The Chinese Experience in Maintaining Undisrupted Learning in COVID-19 Outbreak. Retrieved from https://iite.unesco.org/wp-content/uploads/2020/03/Handbook-on-Facilitating-Flexible-Learning-in-COVID 
-19-Outbreak-SLIBNU-V1.2-20200315.pdf

Jesse, G. R. (2015). Smartphone and App Usage Among College Students: Using Smartphones Effectively for Social and Educational Needs. Retrieved from http://proc.iscap.info/2015/pdf/3424.pdf

Jung, I. (2005). ICT-Pedagogy Integration in Teacher Training: Application Cases Worldwide. Journal of Educational Technology \& Society, 8(2).

Kuh, G. D., \& Hu, S. (2001). The relationships between computer and information technology use, student learning, and other college experiences. Journal of College Student Development, 42, 217-232.

Lanzilotti, R., Ardito, C., Costabile, M. F., \& De-Angeli, A. (2006). ELSE methodology : a systematic approach to the e-learning systems evaluation. Educational Technology \& Society, 9(4), 42-53.

Lee, Y., Hsiao, C., \& Ho, C. H. (2014). The effects of various multimedia instructional materials on students' learning responses and outcomes: A comparative experimental study. Computers in Human Behavior, 40, 119-132. https://doi.org/10.1016/j.chb.2014.07.041

Levitt, H. M. (2018). How to conduct a qualitative meta-analysis: Tailoring methods to enhance methodological integrity. Review PMID, 28(3), 367-378. https://doi.org/10.1080/10503307.2018.1447708

Li, S., Yamaguchi, S., \& Takada, J.-i. (2018). Understanding factors affecting primary school teachers' use of ICT for student-centered education in Mongolia. International Journal of Education and Development using Information and Communication Technology, 14(1), 103-117.

Lilllejord, S., Børte, K., \& Ruud, E. (2018). Teaching and Learning With Technology in Higher Education.

Mirzajani, H., Mahmud, R., Fauzi Mohd Ayub, A., \& Wong, S. L. (2016). Teachers' acceptance of ICT and its integration in the classroom. Quality Assurance in Education, 24(1), 26-40.

https://doi.org/10.1108/QAE-06-2014-0025

Murgatrotd, S. (2020). COVID-19 and Online Learning.

O'Sullivan, D. (2018). Schools' role in addressing the Digital Native Fallacy. Retrieved from http://www.bcs.org/content/ConWebDoc/55719

Prensky, M. (2001). Digital Natives, Digital Immigrants. On the Horizon, 9(5), 1-6. https://doi.org/10.1108/10748120110424816

Ruzgar, N. S. (2005). A Research on the Purpose of Internet usage and learning via internet. The Turkish Online Journal of Educational Technology, 4(4).

Sadegül Akbaba, A., Kalayci, E., \& Avci, Ü. (2011). Integrating ICT at the Faculty Level: A Case Study. TOJET : The Turkish Online Journal of Educational Technology, 10(4).

Shava, H., Chinyamurindi, W., \& Somdyala, A. (2016). An investigation into the usage of mobile phones among technical and vocational educational and training students in South Africa. South African Journal of Information Management, 18(1), 1-8. http://dx.doi.org/10.4102/sajim.v18i1.716

Sipilä, K. (2011). No pain, no gain? Teachers implementing ICT in instruction. Interactive Technology and Smart Education, 8(1), 39-51. http://dx.doi.org/10.1108/17415651111125504

Smith, J. A., \& Judd, J. (2020). COVID-19: Vulnerability and the power of privilege in a pandemic. Health Promotion Journal of Australia, 31(2), 158-160. http://dx.doi.org/10.1002/hpja.333

Sommer, H. (2014). Digital competence study. Intermediate results. Retrieved from https://www.youtube.com/watch?v=BtAFgBiTb5g

Stadler-Altmann, U. (2015). Learning Environment: The Influence of School and Classroom Space on Education. p. 252-262.

Tapscott, D. (1998). Growing Up Digital: The Rise of the Net Generation. New York: McGraw-Hill.

Thomas, O. O., \& Israel, O. O. (2013). Effectiveness of animation and multimedia teaching on students' performance in science subjects. British Journal of Education, Society \& Behavioural Science, 4(2), 201-210. https://doi.org/10.9734/BJESBS/2014/3340

UNESCO. (2020). COVID-19 Educational Disruption and Response. Retrieved from https://en.unesco.org/covid19/educationresponse/

Vrasidas, C. (2015). The rhetoric of reform and teachers' use of ICT. British Journal of Educational Technology, 46(2), 370-380. https://doi.org/10.1111/bjet.12149 
Willms, J. D., \& Corbett, B. A. (2003, Summer). Tech and teens: access and use [2000 data]. Canadian Social Trends, 15-20.

World Bank. (2020a). Guidance Note: Remote Learning \& COVID-19. Retrieved from http://documents.worldbank.org/curated/en/531681585957264427/pdf/Guidance-Note-on-Remote-Learning -and-COVID-19.pdf

World Bank. (2020b). Remote Learning and COVID-19 The use of educational technologies at scale across an education system as a result of massive school closings in response to the COVID-19 pandemic to enable distance education and online learning. Retrieved from file:///E:/PC/Rapid-Response-Briefing-Note-Remote-Learning-and-COVID-19-Outbreak.pdf

Yuen, A., \& Ma, W. (2002). Gender differences in teacher computer acceptance. Journal of Technology and Teacher Education, 10(3), 365-382.

Yunus, M. M. (2007). Malaysian ESL teachers' use of ICT in their classrooms: expectations and realities. ReCALL : the Journal of EUROCALL, 19(1), 79-95. https://doi.org/10.1017/S0958344007000614

Zhang, W., Wang, Y., Yang, L., \& Wang, C. (2020). Suspending ClassesWithout Stopping Learning: China's Education Emergency Management Policy in the COVID-19 Outbreak. Journal of Risk and Financial Management, 13(55), 1-6. https://doi.org/10.3390/jrfm13030055

\section{Copyrights}

Copyright for this article is retained by the author(s), with first publication rights granted to the journal.

This is an open-access article distributed under the terms and conditions of the Creative Commons Attribution license (http://creativecommons.org/licenses/by/4.0/). 